5. Standart ISO 9000-2007. Standarty i rekomendatsiyi shchodo zabezpechennya yakosti v Evropeyskomu prostori vyshchoyi osvity [Tekst]. - K. : Lenvit, 2006. - 36 s.

6. Ts'olner E. Istoriya Avstriyi / per. z nim. R. Dubasevych, KH. Nazarkevych, A. Onyshko, N. Ivanychuk. - Lviv : Litopys, 2001. $-712 \mathrm{~s}$.

7. 7.Engelbrecht H. Geschichte des österreichischen Bildungswesens. 1. Von den Anfängen bis in die Zeit des Humanismus / - Wien : Oesterreichische Bundesverlag, 1982. - $472 \mathrm{~s}$.

8. Satzung der Alpen-Adria-Universität Klagenfurt. Teil C : Verfahrensbestimmungen. - [El. source]. Access : http://www.uni-klu.ac.at/rechtabt/downloads/Satzung_Teil_C.pdf.

Одержано статтю: 5.11.2018

Прийнято до друку: 19.11.2018

УДК 378.147.091.33-027.22

DOI:10.15330/esu.14.38-44

\author{
Людмила Мельниченко, \\ аспірант, ДВНЗ “Переяслав-Хмельницький \\ державний педагогічний університет імені Григорія \\ Сковороди" (м. Переяслав-Хмельницький, Україна) \\ Lyudmyla Melnychenko, \\ Post-graduate student, SHEI "Grogorii Skovoroda \\ Pereiaslav-Khmelnytskyi State Pedagogical University" \\ (Pereiaslav-Khmelnytskyi, Ukraine) \\ lyu.mel19@gmail.com
}

\title{
ПРОЦЕС ФОРМУВАННЯ ДОСЛІДНИЩЬКИХ УМІНЬ МАЙБУТНІХ УЧИТЕЛІВ ПОЧАТКОВОЇ ШКОЛИ У ПЕДАГОГІЧНІЙ ТЕОРЇ̈ ТА ПРАКТИЦІ
}

\section{THE PROCESS OF FORMING OF FUTURE PRIMARY SCHOOL TEACHERS' RESEARCH SKILLS IN PEDAGOGICAL THEORY AND PRACTICE}

У статті проаналізовано украӥнський досвід організачії процесу формування дослідницьких умінь майбутніх учителів початкової иколи.

3'ясовано, шо формування дослідницьких умінь студентів спеціальності "Початкова освіта" с важсливою складовою їхньої професійної підготовки й актуальною темою вивчення. Науковиями визначено зміст дослідниьких умінь майбутніх учителів початкової иколи, розроблено їхню структуру та класифікацію, визначено ефективні педагогічні умови та засоби їх формування. Дослідницькі вміния розглянуто як невід'смний елемент дослідницької компетентності майбутнього вчителя початкової иколи та його готовності до проведения педагогічних досліджень, а відтак - професійної компетентності та готовності до майбутньої професійної діяльності. Встановлено, що організувати досліднииьку діяльність учнів початкових класів здатний учитель, який сам володіє відповідними знаннями та вміннями проводити дослідження Серед визначених науковчями педагогічних умов організаџіі прочесу формування дослідницьких умінь майбутиіх учителів початкової иколи увагу, в периу чергу, зосереджусмо на важливості таких: усвідомлення студентами значення оволодіння вміннями чього виду, психологопедагогічна компетентність викладача; оріснтачія на модель майбутньої діяльності студентів, комплексний підхід до організачії освітнього прочесу; поєднання наукової та навчальної роботи. Ученими теоретично обтрунтовано та експериментально перевірено застосування у прочесі формування дослідницьких умінь модульної організації навчання, самостійної роботи, навчально-рольової гри, контролю знань $і$ вмінь, педагогічної практики, проектної діяльності. Проте Нова украӥнська школа в контексті освітньої реформи вимагає оновлення змісту ивого прочесу, почуку нових підходів його організачії. Серед таких підходів розглядасмо інновачійний та інтегральний, ио передбачають упровадження інновачійних технологій навчання (BYOD, SMART, STEM, STEAM), які трунтуються на інтеграчії наукових методів пізнання, технологій, техніки, математики та мистечтва. $У$ з6'язку із чим на часі є вивчення дидактичного потенціалу інновачійних 
технологій у прочесі формування дослідницких умінь майоутніх учителів початковой иколи.

Ключові слова: дослідшицькі вміния майбутніх учителів початкової иколи, інтегральний підхід, інновачійний підхід, професійна підготовка, формування.

The article is devoted to the study the Ukrainian experience of organizing the process of forming the research skills of future teachers of elementary school.

The scientific interest to the process of forming the research skills of students of the specialty "Primary education" is markedly increasing during the years of independence of the Ukrainian state and scientific and technological progress, when there is a need in teachers who can not only teach, but also study, research and implement research results. The analysis of the scientific foundation shows that the formation of research skills of future primary school teachers is an important component of their vocational training and an actual topic of study. The researchers determined the content of research skills of students of the specialty "Primary education", developed their structure and classification, determined the effective pedagogical conditions and the means of their formation. Research skills are an integral part of the research competence of the future teacher of primary school and his willingness to conduct pedagogical research, and hence - professional competence and readiness for future professional activity. The scientists identified 12 pedagogical conditions necessary for ensuring the process of formation of research skills; in the first place, we emphasize the importance of the following: the students' awareness of the importance of mastering the skills of this type, the psychological and pedagogical competence of the teacher of higher school; orientation to the model of future students' activity, integrated approach to the organization of the educational process; $a$ combination of scientific and educational work. Scientists have theoretically substantiated and experimentally tested the application in the process of formation of research skills of the modular organization of training, independent work, educational role-playing, control of knowledge and skills, pedagogical practice, project activity. However, the New Ukrainian School in the context of educational reform requires updating the content of this process, seeking new approaches to its organization, among them - innovative and integrated, involving the introduction of innovative learning technologies (BYOD, SMART, STEM, STEAM), which are based on the integration of scientific methods of cognition, technological tools, hardware, math and art.

Key words: research skills of future teachers of primary school, integral approach, innovative approach, professional training, formation

Постановка проблеми. Науковий інтерес до процесу формування дослідницьких умінь студентів спеціальності “Початкова освіта" помітно зростає у роки незалежності української держави та науково-технічного прогресу, коли з'являється потреба у педагогах, які вміють не тільки вчити, а й вивчати, досліджувати та впроваджувати результати досліджень. Реалізація концепції Нової української школи та затвердження Професійного стандарту вчителя початкових класів актуалізують необхідність у зіставленні педагогічного досвіду організації означеного процесу та вимог часу.

Аналіз останніх досліджень і публікацій. Різні аспекти професійної підготовки майбутніх учителів початкової школи висвітлено у дослідженнях Коваль Л. В., Комар О. А, Красюк Л. В., Пащенка Д. І., Савченко О. Я., Чумахідзе Т. Л., Ярошинської О. О. й інших.

Процес формування дослідницьких умінь студентів спеціальності "Початкова освіта" розкрито у наукових розвідках Мишковської Т. Д. [9]., Балашової С. П. [2]., Степанюк К. І. [12]., дослідницької компетентності - Ваколі Т. І. [3]., готовності до проведення педагогічних досліджень - Коржової Л. С. [7], професійної рефлексії - 
Марусинець М. М. [8]. Значення інтегрального підходу у процесі формування самоосвітньої компетентності майбутніх учителів початкової школи обгрунтувала Ігнатенко Н. В. [5].

Виділення невирішених раніше частин проблеми. Актуальним, але мало вивченим, $\epsilon$ питання узагальнення педагогічного досвіду організації процесу формування дослідницьких умінь майбутніх учителів початкової школи, окреслення пріоритетних підходів до вдосконалення цього процесу.

Мета статті - вивчити вітчизняний педагогічний досвід організації процесу формування дослідницьких умінь майбутніх учителів початкової школи.

Постановка завдання. Досягнення мети передбачає виконання таких завдань: виявити розроблені науковцями шляхи формування дослідницьких умінь майбутніх учителів початкової школи, обгрунтувати необхідність застосування у цьому процесі інноваційного й інтегрального підходів.

Виклад основного матеріалу. У Законі України “Про вищу освіту" вказано, що студенти мають право на "участь у науково-дослідних, дослідно-конструкторських роботах, конференціях, симпозіумах, виставках, конкурсах, представлення своїх робіт для публікації" [4]. Реалізація цього права забезпечується у процесі професійної підготовки у закладах вищої освіти.

Марусинець М. М. розглядає професійну підготовку майбутніх учителів початкової школи у тісному зв'язку із їх професійно-особистісним становленням, що передбачає прагнення до певного ідеалу та самовдосконалення. Чинником професійного становлення дослідниця визначає професійну рефлексію, що охоплює самодослідження, самоконтроль, самопізнання, саморегуляцію; у ії складі виділяє аксіологічний, когнітивний, особистісний, емоційно-оцінний, операційно-технологічний елементи. Рефлексивний процес відіграє важливу роль у професійній діяльності майбутнього вчителя, оскільки, як зазначає Марусинець М. М., "педагог займає активну дослідницьку позицію щодо своєї діяльності і себе як суб'єкта 3 метою їі конструктивного перетворення і вдосконалення" [8, с. 108].

Чумахідзе Л. В., характеризуючи сутність професійної підготовки майбутніх учителів початкової школи, акцентує увагу на процесах формування та розвитку, результатом яких $\epsilon$ професійна компетентність і готовність до професійної діяльності. Професійну компетентність дослідниця визначає через сукупність різних видів знань, умінь і здатностей, а у складі загальної професійної готовності майбутніх учителів початкових класів виділяє готовність до організації дослідницької роботи молодших школярів у природі і визначає їі як складне утворення й інтегративну якість, що забезпечують, за іiі словами, “формування ціннісного ставлення до природи, вмінь організовувати дослідницьку роботу учнів під час вивчення природознавства" $[13$, с. $7-8]$.

Miєp Т. І., вивчаючи дидактичні засади навчально-дослідницької діяльності в початковій школі, також закцентувала увагу на значенні готовності вчителя до організації цього процесу. В його основі розглядається здатність і прагнення, що поєднують мотиваційний, діяльнісний та рефлексивний компоненти 3 метою забезпечення, як зазначає дослідниця, “організації процесу відкриття учнями суб’єктивно нових знань і способів дій” [10, с. 108].

Аналізуючи праці Чумахідзе Т. Л. та Мієр Т. І., можна зробити висновок, що організувати дослідницьку діяльність молодших школярів здатний учитель, який володіє не тільки дидактичними вміннями, а й уміннями проводити дослідження. 
У Професійному стандарті “Вчитель початкових класів закладу загальної середньої освіти", затвердженому 10 серпня 2018 р., однією із трудових функцій визначено “проведення педагогічних досліджень", що передбачає виконання відповідних дій і операцій: “визначення методичної проблеми, обгрунтування iї актуальності, мети, завдань тощо; розроблення концепції дослідження” та інші [11, с. 30].

Одиницею вимірювання здатності до проведення дослідження Амеліна Н. С. називає вміння, а дослідницькі вміння розглядає як “елементарну частку дослідницької діяльності" [1, с. 143].

Дослідницькі вміння майбутніх учителів початкової школи $є$ предметом вивчення Мишковської Т. Д. [9], Балашової С. П. [2], Степанюк К. І. [12]. Науковцями з'ясовано зміст цих умінь, розроблено модель їх формування,

визначено педагогічні умови, підібрано ефективні засоби.

Мишковська Т. Д. охарактеризувала дослідницько-педагогічні вміння як сукупність “спеціальних знань і навичок”, необхідних, як стверджує науковець, “для виконання дослідницьких дій” [9, с. 74]. В основі дослідницьких умінь Балашова С. П. розглядає “властивість особистості", їх функція полягає, за словами вченої, в організації та проведенні “пошуково-перетворюючої діяльності” [2, с. 34]. Степанюк К. І. розглядає цей вид умінь як “інтегроване утворення розумових i практичних дій”, необхідних, на думку науковця, для виконання "пошукової діяльності" [12, с. 6].

У структурі дослідницьких умінь, розробленою Балашовою С. П., виділено аналітико-синтетичні, інформаційні, креативні та прогностичні вміння, а у класифікації Степанюк К. І., виконаної на основі видів пошукової діяльності, виокремлено такі їні групи: технологічно-проектувальні, когнітивно-операційні, організаційнопошукові, комунікативно-рефлексивні.

Науковцями здійснено спробу вдосконалити процес формування дослідницьких умінь різними шляхами.

Мишковська Т. Д. розробила методику формування дослідницько-педагогічних умінь в умовах модульної організації навчання, що складається із модулів, цільової програми діяльності, висновків-резюме про підсумковий контроль. Обгрунтувала значення різнорівневого рейтингового контролю результатів навчання студентів. Сформованість дослідницьких умінь Мишковська Т. Д. розглядає як "багаторівневу характеристику особистості", зміст якої визначається мотивами, установками, станами, дослідницькими знаннями, навичками i вміннями та залежить, на її думку, від “характеру й умов педагогічної діяльності” [9, с. 74].

Балашовою С. П. розроблено педагогічну технологію формування дослідницьких умінь студентів педагогічного коледжу під час вивчення дисциплін природничого циклу, що вмістила педагогічне оцінювання рівня сформованості вмінь, відбір змісту навчального матеріалу, форм і методів, систему дидактичних завдань і контроль. Обгрунтовано значення самостійної роботи, навчально-рольової гри, контролю знань і вмінь, педагогічної практики. Процес формування побудовано із мотиваційного, процесуального та дослідницького етапів і охарактеризовано як створення сприятливих умов для особистісних якостей і професійних умінь, що в кінцевому результаті визначають, як зазначено вченою, “подальший професійний розвиток і саморозвиток учителя як дослідника" [2, с. 184].

Степанюк К. І. розробила модель формування дослідницьких умінь, що складається із трьох блоків (теоретичного, операційно-діяльнісного, критеріально-оцінного) та грунтується на компетентнісному, технологічному, діяльнісному підходах. 
Оцінка сформованості вмінь здійснювалася за мотиваційним, когнітивним, операційним критеріями та трьома рівнями: високим, середнім, низьким. Ефективним засобом формування дослідницьких умінь визначено проектну діяльність “комплекс дій, пов'язаних з реалізацією процесу проектування” [12, с. 6-7].

Науковцями визначено 12 педагогічних умов (Мишковська Т. Д. - 4, Балашова С. П. - 5, Степанюк К. І. - 3), необхідних для забезпечення процесу формування дослідницьких умінь; увагу, в першу чергу, зосереджуємо на важливості таких:

- усвідомлення студентами значення оволодіння вміннями цього виду, психолого-педагогічна компетентність викладача вищої школи [2, с. 187];

- орієнтація на модель майбутньої діяльності студентів, комплексний підхід до організації навчання [9, с. 171];

- поєднання наукової та навчальної роботи [12, с. 7].

- Дотичними до означеного кола досліджень $є$ праці Коржової Л. С. і Ваколі Т. І.

Коржова Л. С. визначила зміст поняття "готовність майбутніх учителів початкових класів до проведення педагогічних досліджень", розглядаючи в ньому утворення, що складається із прагнення до науково-дослідницької роботи, знань і вмінь організовувати педагогічний науковий пошук. Серед діагностичних критеріїв цього утворення названо дослідницькі вміння. Підготовка студентів до проведення досліджень розглядається як процес, що, за словами науковця, “здійснюється шляхом раціонального поєднання ефективних освітніх технологій i природної активності людини до саморозвитку" [7, с. 18].

Ваколею Т. І. обгрунтовано поняття “дослідницька компетентність майбутнього вчителя початкових класів" як складне утворення, що поєднує вмотивованість, досвід, професійну спрямованість і здатність до рефлексіі. Розроблено й експериментально перевірено структурно-функціональну модель формування компетентності, яка вмішує змістово-методичний, організаційно-технологічний, оціннодіагностичний блоки та реалізується у чотири етапи: діагностико-прогностичний, інформаційний, практичний, творчо-евристичний. Впроваджено спецкурси “Введення в педагогічне дослідження", “Дослідно-експериментальна робота в навчальних закладах", “Організація i проведення експерименту в психолого-педагогічному дослідженні". Суттю формування готовності до проведення наукових досліджень визначено цілеспрямований професійно-педагогічний вплив на студента, результатом чого $\epsilon$, як зазначає дослідниця, “розвиток його наукового потенціалу” [3, с. 13].

Отже, дослідницькі вміння є одним із елементів дослідницької компетентності майбутнього вчителя початкової школи та його готовності до проведення педагогічних досліджень, а відтак - професійної компетентності та готовності до майбутньої професійної діяльності. У наукових розвідках висвітлено різні аспекти процесу формування дослідницьких умінь студентів спеціальності "Початкова освіта", проте у контексті освітньої практики ця проблема залишається недостатньо вивченою.

У Концептуальних засадах реформування середньої освіти зазначено: “багато педагогів ще не вміє досліджувати проблеми за допомогою сучасних засобів” [6, с. 4]. Такий факт актуалізує проблему формування дослідницьких умінь майбутніх учителів початкової школи та спонукає до пошуку нових підходів до ії вирішення, серед яких - інноваційний та інтегральний.

Інноваційний підхід передбачає впровадження інноваційних освітніх практик: BYOD, SMART, STEM, STEAM та інших, що грунтуються на інтеграції наукових 
методів пізнання, технологічних інструментів, технічних засобів, математики, мистецтва тощо.

Значення інтегрального підходу у професійній підготовці студентів спеціальності "Початкова освіта" обгрунтовано Ігнатенко Н. В. Його охарактеризовано як особливу форму організації пізнавальної діяльності, у якій поєднано зміст, систему ідей і принципів. На нинішньому етапі розвитку освіти такий підхід визначається інноваційним i перспективним напрямом дослідження, оскільки, як зазначає Ігнатенко Н. В., “дозволяс реалізувати ідеї інтеграції в системі підготовки майбутніх учителів початкових класів" [5, с. 418].

Висновки. Аналіз наукового фонду свідчить, що формування дослідницьких умінь майбутніх учителів початкової школи $\epsilon$ важливою складовою їхньої професійної підготовки й актуальною темою вивчення. Науковцями з'ясовано зміст дослідницьких умінь студентів спеціальності “Початкова освіта", розроблено їхню структуру та класифікацію, визначено ефективні засоби їх формування, серед них: модульна організація навчання, самостійна робота, навчально-рольова гра, контроль знань і вмінь, педагогічна практика, проектна діяльність. Проте Нова українська школа в контексті освітньої реформи вимагає вдосконалення цього процесу на основі інноваційного й інтегрального підходів.

Перспективи подальших розвідок передбачають вивчення дидактичних можливостей інноваційних технологій у процесі формування дослідницьких умінь майбутніх учителів початкової школи.

\section{Література}

1. Амелина Н. С. Учебно-исследовательская деятельность студентов педвузов (в процессе изучения дисциплин педагогического цикла) : дисс. ... кандидата пед. наук : 13.00.01. Киев, $1981.210 \mathrm{c}$.

2. Балашова С. П. Формування дослідницьких умінь у студентів педагогічного коледжу в процесі вивчення природознавчих дисциплін : дис. ... кандидата пед. наук : 13.00.04. Київ, $2000.274 \mathrm{c}$.

3. Ваколя Т. І. Формування дослідницької компетентності майбутніх учителів початкових класів у процесі професійної підготовки : автореф. дис. ... канд. пед. наук : спец. 13.00 .0404 "Теорія і методика професійної освіти". Херсон, 2014. 20 c.

4. Закон України "Про вищу освіту” від 01.07.2014 №1556-VII із змінами та доповненнями. URL: http://zakon3.rada.gov.ua/laws/show/1556-18/ page

5. Ігнатенко Н. В. Умови формування самоосвітньої компетентності майбутнього педагога. Гуманітарний вісник ДВНЗ "Переяслав-Хмельницький державний педагогічний університет імені Григорія Сковороди”. 2013. Вип. 28. С. $414-419$.

6. Концептуальні засади реформування середньої освіти, 2016. 34 с. URL: https://www.kmu.gov.ua/storage/app/media/reforms/ukrainska-shkola-compressed. pdf.

7. Коржова Л. С. Формування готовності майбутніх учителів початкових класів до проведення педагогічних досліджень : автореф. дис. ... канд. пед. наук : спец. 13.00.04 “Теорія і методика професійної освіти". Кривий Ріг, 2002. 24 с.

8. Марусинець М. М. Система формування професійної рефлексії майбутніх учителів початкових класів : дис. ... доктора пед. наук : 13.00.04. Івано-Франківськ, 2012. 454 с.

9. Мишковська Т. Д. Формування дослідницько-педагогічних умінь студентів в умовах модульної організації процесу навчання : дис. .. кандидата пед. наук : 13.00.01. Тернопіль, 1999. $322 \mathrm{c}$.

10. Мiєр Т. I. Дидактичні засади організації навчально-дослідницької діяльності молодших школярів : дис. ... доктора пед. наук : 13.00.09. Київ, 2017. 594 с.

11. Професійний стандарт "Вчитель початкових класів закладу загальної середньої освіти": Наказ Міністерства соціальної політики України №1143 від $10.08 .2018 \mathrm{p}$. 45 с. URL: https://www.msp.gov.ua/files/News/20180815/ 20180815. pdf 
12. Степанюк К. I. Формування дослідницьких умінь майбутніх учителів початкової школи у процесі проектної діяльності : автореф. дис. ... канд. пед. наук : спец. 13.00.04 "Теорія і методика професійної освіти". Бердянськ, 2013. 20 с.

13. Чумахідзе Т. Л. Підготовка майбутніх учителів початкових класів до організації дослідницької роботи молодших школярів у природі: автореф. дис. ... канд. пед. наук : 13.00 .04 "Теорія i методика професійної освіти". Ялта, 2013. 20 с

\section{References}

1. Amelina, N. S. (1981). Uchebno-issledovatelskaya deyatelnost studentov pedvuzov (v protsesse izucheniya dystsyplin pedagogycheskogo tsykla) [Teaching and research activities of students of higher educational establishment (in the process of studying the disciplines of the pedagogical cycle)] : Candidate's thesis: 13.00.01. Kiev, Ukraine (russ).

2. Balashova, S. P. (2000). Formuvannia doslidnytsykh umin u studentiv pedahohichnoho koledzhu $v$ protsesi vyvchennia pryrodoznavchykh dystsyplin [Formation of research skills among students of the pedagogical college in the process of learning disciplines of natural sciences] : Candidate's thesis: 13.00.04. Kyiv, Ukraine (ukr).

3. Vakolya, T. I. (2014). Formuvannia doslidnytskoi kompetentnosti maibutnikh uchyteliv pochatkovykh klasiv u protsesi profesiinoi pidhotovky [Formation of research competence of future teachers of primary school in the process of professional training] : Extended abstract of candidate's thesis : spets.13.00.04 "Teoriia i metodyka profesiinoi osvity". Kherson, Ukraine (ukr).

4. Zakon Ukrainy "Pro vyshchu osvitu" [Law of Ukraine "On Higher Education"] vid 01.07.2014 № 1556-VII iz zminamy ta dopovnenniamy. Retrieved from: http://zakon3.rada.gov.ua/laws/show/ 1556-18/page (ukr).

5. Ihnatenko, N. V. (2013). Umovy formuvannia samoosvitnoi kompetentnosti maibutnoho pedahoha [Conditions for the formation of self-educational competence of the future teacher]. Humanitarian Herald of SHEI "Grogorii Skovoroda Pereiaslav-Khmelnytskyi State Pedagogical University",28, $414-419$ (ukr).

6. Konceptualni zasady reformuvannia serednoi osvity [Conceptual Principles of Reforming Secondary Education]. (2016). Retrieved from: https://www.kmu. gov.ua/storage/app/media/reforms/ukrainskashkolacompressed. pdf. (ukr).

7. Korzhova, L. S. (2002). Formuvannia hotovnosti maibutnikh uchyteliv pochatkovykh klasiv do provedennia pedahohichnykh doslidzhen [Formation of the readiness of future teachers of primary school to conduct pedagogical research] : Extended abstract of candidate's thesis : spets.13.00.04 "Teoriia i metodyka profesiinoi osvity". Kryvyi Rig, Ukraine. (ukr).

8. Marusynets, M. M. (2012). Systema formuvannia profesiinoi refleksii maibutnikh uchyteliv pochatkovykh klasiv [System of formation of professional reflection of future teachers of primary school] : Doctor's thesis: 13.00.04. Ivano-Frankivsk, Ukraine (ukr).

9. Myshkovska, T. D. (1999). Formuvannia doslidnytsko-pedahohichnykh umin studentiv v umovakh modulnoi organizatsii protsesu navchannia [Formation of research and pedagogical skills of students in conditions of modular organization of the learning process] : Candidate's thesis: 13.00.01. Ternopil, Ukraine (ukr).

10. Miier, T. I. (2017). Dydaktychni zasady organizaitsii navchalno-doslidnytskoi diialnosti molodshykh shkoliariv [Didactic principles of organization of teaching and research activity of junior pupils]: Doctor's thesis : 13.00.09. Kyiv, Ukraine (ukr).

11. Profesiinyi standart "Vchytel pochat kovykh klasiv zakladu zahalnoi serednoi osvity" [Professional Standard "Teacher of Primary School of General Secondary Education"] : Nakaz Ministerstva sotsialnoi polityky Ukrainy № 1143 vid 10.08.2018r. Retrieved from: https://www.msp.gov.ua/files/News/20180815/201808 15.pdf (ukr).

12. Stepaniuk, K. I. (2013). Formuvannia doslidnytskykh umin maibutnikh uchyteliv pochatkovoi shkoly u protsesi proektnoi diialnosti [Formation of research skills of future teachers of primary school in the process of project activity] : Extended abstract of candidate's thesis : spets.13.00.04 "Teoriia i metodyka profesiinoi osvity". Berdiansk, Ukraine (ukr).

13. Chumahidze, T. L. (2013). Pidhotovka maibutnikh uchyteliv pochatkovykh klasiv do organizatsii doslidnytskoi roboty molodshyh shkoliariv u pryrodi Preparation of future primary school teachers for the organization of research work of junior schoolchildren in the nature] : Extended abstract of candidate's thesis : spets. 13.00.04 "Teoriia i metodyka profesiinoi osvity". Yalta, Ukraine (ukr). 